\title{
Devika Sharma
}

\section{The Captive Imagination: Inhumanity, Animality, and Matthew Barney's Cremaster 2}

The convict is a paradigmatic figure of the "animality" of the human. Since prison is typically perceived, pace Foucault, to be a fundamentally dehumanizing location, we tend to think of people who have been imprisoned for longer periods of time as being challenged on their humanity. Incarceration and isolation not only do something to people, we imagine, but more specifically affect their humanity understood in contrast to a more primitive, animal-like state of being, as suggested for instance by the title of the 1977 novel by ex-convict Edward Bunker, The Animal Factory. The fact that convicts are often represented as animals suggests that the animal and the convict may take up identical contrastive functions in the cultural imagination of what it might mean to be human; whereas we routinely put animals in cages, we imprison people who have somehow violated our notions of accepted common human behavior. The convict is regularly framed as less than human, as inhuman, by various discursive and material forms of "animalization," making him or her appear, in Judith Butler's helpful terminology, humanly unrecognizable (98). We may think of the "zebra stripes" on the prototypical prison uniform as such a dehumanizing device. ${ }^{1}$ The common conception of prison as a kind of zoo is likewise invoked when TV channels such as National Geographic broadcast docu-soaps from notorious US prisons amid wildlife programs with titles such as "Predators of the Sea" and "Hornets from Hell." Metaphors matter, and the cultural metaphor of the animal-like convict continues to have material consequences for the social, legal, and political status of prison populations nationally and globally. ${ }^{2}$

Setting out from American artist Matthew Barney's film Cremaster 2 (1999), the latter part of this essay explores the significance of ideas of captivity and incarceration for contemporary concepts of inhumanity and animality. Captivity and confinement are, of course, in themselves favored objects of the popular imagination, but what I want to draw our attention to is a fact suggested by Barney's film, namely that notions of captivity typically operate as part of the framework through which we imagine aspects of inhumanity and animality. In Barney's peculiar piece of avant-garde cinema the major roles are played by an emblematic convict, a lot of animals, and an escape artist. In the pages ahead I explore the ways in which Barney employs these characters to reflect on the boundaries of the human. In order to do so, I relate the film to two lines of contemporary theoretical reflection. The first considers what we may term "the question 
of the inhuman" and it involves the work of thinkers such as Gilles Deleuze, Felix Guattari, Eric Santner, Giorgio Agamben, Slavoj Žižek, and Judith Butler. The second line considers in turn "the question of the animal" and engages work within the field of posthumanism and animal studies, including works by Jacques Derrida, Nicole Shukin, and Cary Wolfe. ${ }^{3}$

Generally speaking, and reflected by these two lines of research, our common concepts of the human bring two boundaries into play: an external limit, where the human borders on the animal, and an internal limit, where the human is defined against shifting figures of inhumanity. Recent scholarship on the relations between animality and biopolitics has, however, critically examined the ways in which the canonical literature on biopolitics - including the thinkers mentioned in the first category outlined above - typically employ the figure of the animal to reflect on what I here term the "internal" boundary of humanity. Rather than furthering an understanding of the functions of actual non-human animals in biopolitical government, the figure of the animal is most often invoked to throw light on processes of dehumanization. Demonstrating the importance of the distinction "human/animal" for the workings of biopower, Cary Wolfe in his recent book Before the Law: Humans and Other Animals in a Biopolitical Frame (2012) wonders why "the main line of biopolitical thought has had little or nothing to say about how this logic effects nonhuman beings" (10). In a similar vein Steven Connor writes, after mentioning that according to Michel Foucault in Madness and Civilisation (1964) madness at the beginning of the seventeenth century was correlated with animality: "the real amazement is how, after this brief dalliance with the subject of animals, the inaugurator of the notion of biopower [Foucault] could have succeeded in ignoring it for the rest of his career, despite his corrosive scepticism regarding the idea of 'the human'" (579). As Nicole Shukin sums up in her book Animal Capital: Rendering Life in Biopolitical Times (2009):

If biopolitical critique has largely bracketed the question of the animal, critical theory and the emergent field of animal studies have [...] tended to sidestep materialist critique in favor of philosophical, psychoanalytical, and aesthetic formulations of animal alterity. (12)

What these evaluations have in common, then, is a critique of biopolitical thought for abstracting the animal into a mere figure for the kind of dehumanization and animalization of the human implied in, for instance, colonialism, imperialism, and other racist practices. Animals are not merely symbols, these evaluations insist, but also substances. Not merely metaphors, but material matter, complex living beings and

Humanimalia: a journal of human/animal interface studies

Volume 6, Number 2 (Spring 2015) 
fodder for capital in biopolitical times. What distinguishes the functions of biopower today, these materialist critiques suggest, is not only that they continuously produce and reproduce the internal limit defining man against shifting figures of inhumanity, but also that they are deeply invested in producing, administering, distributing, and consuming animal life as, precisely, life that has been rendered too abstract and ghostly to count as an object of politics.

What makes Barney's Cremaster 2 relevant in this context is, first, the fact that the film examines the logic of both the internal and the external boundaries of the human as these boundaries are put into play by the figure of the convict, by some remarkably unorthodox animal coactors, and by a general entanglement throughout the film of human and animal lives. The film establishes close links between these two boundaries of the human, and in doing so it seems to suggest that these limits always interact, and that a critique of the production of inhumanity therefore should take into consideration also the lives of animals. Second, Cremaster 2 suggests that captivity and imprisonment are actively functioning frames for imagining and governing the two boundaries of the human. Re-imagining and re-negotiating the meaning of these boundaries would thus imply analyzing historical and contemporary practices of capture and confinement as well as notions of freedom.

An oft-heard critique of Matthew Barney is that his work is too speculative and aesthetically self-sufficient to have anything to do with the contemporary, surrounding world. As I see it, however, Cremaster 2 examines an issue with great political relevance today, namely the ways in which we negotiate the discursive and material boundaries of humanity and animality. ${ }^{4}$ Cremaster 2, as Barney's work in general, is not a very straightforward "discussion" or "suggestion" of anything. To describe the film as a critique of animal sacrifice under biopolitical conditions or of the animalization of U.S. convicts would be a forced reading. I have nevertheless found it fair to see in this film a visual engagement with captivity and its significance for the discourses, images, and institutions that govern the boundaries of the human. My overall hypothesis is that Cremaster 2 prompts us, as does some of the theoretical work done on the question of the inhuman and the question of the animal, to scrutinize more carefully the implications of thinking with the prison as a framework when imagining inhumanity and animality. While my essay examines this problem mainly from the perspective of Continental and Anglo-American philosophy and cultural theory, it is important to note

Devika Sharma - "The Captive Imagination: Inhumanity, Animality, and Matthew Barney's Cremaster 2" 
that the terrain on which this problem unfolds most significantly is, of course, not theory. The material and institutional histories of thinking human and animal life in terms of differing degrees of freedom and bondage is waiting to be explored further.

Aliens. Matthew Barney may be the American artist who has confronted the boundary between the human and the non-human in the most spectacular fashion. Barney regularly uses Teflon and metals as prosthetics and implants that transform the biological, human body - often his own - into a cybernetic organism. At the same time, he also seeks to humanize the artificial by using a special surgical plastic that shares qualities with human tissue for framing images, so that they appear conceptually to be portals into the human body. This symbolic synthesis of organic and inorganic materials is characteristic of Barney's work, which in general concerns the (trans)formation of the human organism. ${ }^{5} \mathrm{He}$ is known for the alternatingly eccentric, comical, and repulsive expressions in his works, and his aim of taking up - once again to employ Butler's terminology - the humanly unrecognizable is a core reason for the fascination they hold.

Cremaster 2 is a chapter in Barney's major work, The Cremaster Cycle (1994-2003), which is made up of five films: Cremaster 1-5. In addition to the five feature length films, the Cycle includes photographs, drawings, sculpture, and installations forming part of each of the five episodes. Without attempting a proper synopsis of this complex film, it is nevertheless relevant to my discussion that Barney takes up the myth in the Gilmore family that Harry Houdini was in fact Gary Gilmore's grandfather, with whom he identified a particular notion of freedom through self-transformation. In the film Houdini is played by Norman Mailer, who in his The Executioner's Song relates this family myth of kinship.

As a conceptual model for the entire Cycle, Barney has chosen the sexual development of the human embryo. The movies are named after the cremaster muscle, which raises and lowers the testicles in the scrotum, and this slow process towards sexual differentiation during the first trimester of pregnancy is the basic "problem" of the five films. While the abstract, formal model for The Cremaster Cycle is thus the biological production of human beings, the non-human plays a more prominent role on the level of imagery. Particular to the Cremaster universe are a multitude of hybrid beings such as satyrs and other mythical beings, and this very profusion of animal species emphasizes the non-human ambiance of the Cycle. Likewise, we may understand the more "abject" sections of the Cycle - the myriad of spectacular scenes with curious bodily orifices, prosthetics, and fluids, which cannot be given any closer determination - as an

Humanimalia: a journal of human/animal interface studies

Volume 6, Number 2 (Spring 2015) 
invocation and modification of the limits of the human. Due also to the works' impenetrability, The Cremaster Cycle is, in every possible way, a very alien universe. The hybridity of beings is a hallmark of the entire Cycle, but since I am focusing in particular on relations between questions of humanity and notions of confinement, I shall restrict my analysis to Cremaster 2, in which this problem is played out most prominently.

In a sense, Cremaster 2 is a crime-biography. The film is about Gary Gilmore: his birth, crime, and execution. ${ }^{6}$ The historical Gary Gilmore was shot in Utah by a firing squad in 1977 when he was 37 years old, for the murders of Max Jensen and Bennie Bushnell. Before the trial for the two murders Gilmore had already spent most of his life in juvenile penitentiary and prison. At the time the case was a national media event, mainly because Gilmore refused to appeal the verdict, but rather asked for a swift execution of the death penalty. His execution marked the end of a period without death penalties - in the wake of first Furman v. Georgia (1972) and then the Supreme Court decision in Gregg v. Georgia (1976) - and the case was therefore an important turning point in American penal history. Gilmore disturbed a novel tradition of not using the harshest measures, and interest groups justly feared that Gilmore's execution signalled a return to executions on a national scale.

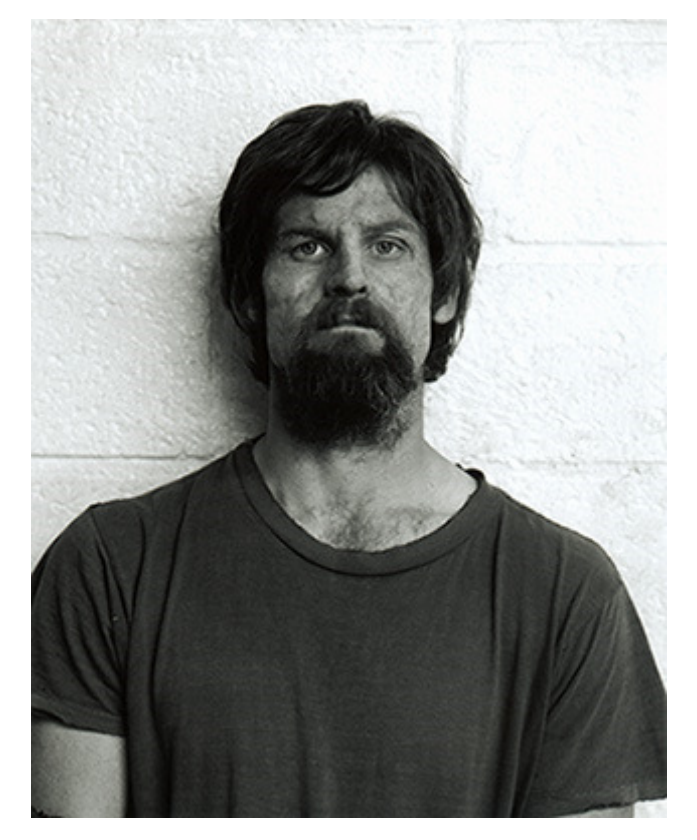

(Matthew Barney as Gary Gilmore; with permission of the artist)

Devika Sharma - “The Captive Imagination: Inhumanity, Animality, and Matthew Barney's Cremaster 2” 
Norman Mailer immortalized Gilmore's story in his extensive work of non-fiction The Executioner's Song, in which Mailer several times emphasizes Gilmore's animal-like features as they were reportedly experienced by his surroundings. ${ }^{7}$ Mailer establishes the familiar symbolic connections between "bestiality" and prison, by describing penitentiaries as "farmlike" ("Introduction" 523) and maximum security prison specifically as "a zoo, a flat one-story zoo with many cages" (483). Especially Mailer's description of the hearings preceding the determination of the death sentence suggests that Gilmore's humanity was at stake. According to Mailer, the challenge for Gilmore's lawyers was to present their client as "a human being" and thereby to modify the jury's impression of him as being "a heartless animal." Later, Gilmore was given a new lawyer, who explained Gilmore's inhuman acts by reference to his "animal life" in prison: "None of us here have spent more than 90 percent of our adult life in the cages where the animals are," the lawyer said in court (533). It seems important to note that these are not Mailer's capricious metaphors, but instances of a persistent image of the convict that resonates with the various forms of dehumanizing prisoners.

In Cremaster 2, Barney has likewise chosen to represent Gary Gilmore as an animal, more specifically as a drone-bee. In the first part of this essay, I suggest that the Gilmore drone is an aesthetic vehicle for visualizing and modifying both the idea of the convict as an animal-person and the common notions of the inhuman more generally. In this regard, it is worth noting that Gilmore's "animality" does not have only negative connotations in Cremaster 2. On the one hand, Barney employs Gilmore's animality to indicate a certain shapelessness, a radically open dimension of the human, which in this aesthetic universe - as it is the case in the work on becoming-animal by Gilles Deleuze and Felix Guattari - constitutes a creative potential. On the other hand, as a convict Gilmore also serves as an instrument in the film for examining inhumanity as a result of being exposed to a certain lawless dimension of the law. In the second part of this essay, I show that Cremaster 2 interprets not only the boundary between the human and inhuman, but also that between human and animal. Finally, in the third part, I draw on the film's envisioning of capture, in order to discuss the extent to which we employ captivity and confinement as frames for thinking the animality of human and nonhuman animals alike.

Two Kinds of Inhumanity: One Good and One Bad. Deleuze and Guattari's notion of "becoming-animal" is an obvious frame of reference for Barney's examination of the marginal areas of the human. As is well-known, this concept was developed in $A$ Thousand Plateaus (1987) and in Kafka: Toward a Minor Literature (1986), where the authors suggested that Franz Kafka's stories are concerned with a special kind of

Humanimalia: a journal of human/animal interface studies

Volume 6, Number 2 (Spring 2015) 
becoming: "becoming-animal." For Deleuze and Guattari becoming-animal implies a particular, creative line of development, which leads away from the self-identical, certain, and therefore static individual psychological set-up, and provides a possible escape from the familial and societal structures that may seem repressive to the individual. The authors also use the concept of "deterritorialization" to exemplify the alternative organization of the human made possible by processes of becoming-animal. Deterritorialization designates the expansion of a territory as a consequence of disrupting a given mode of spatial organization. When man deterritorializes into becoming-animal, he enters into an alliance with an animal and borrows from its intensity. The animal offers the humans a way to transform itself by providing "lines of flight," that is, modes of deterritorialization, which the human could not have thought up by humans on their own. For Deleuze and Guattari, becoming-animal is merely one of several "becomings," which makes it possible for humans to escape their set routines and the psychological regularities that follow.

There is a close conceptual and figurative connection between Barney's aesthetic universe, on the one hand, and Deleuze and Guattari's descriptions of becominganimal, on the other. The conceptual connection is found in Barney's interest in the transition between various states in man and alternative organizations of the human. Barney has in several interviews emphasized that he perceives the characters in his works as personality zones: "There is a lack of character development that interests me - the fact that they can quiver between something understood as a character with agency and something that operates more as a state of some sort, or a zone" (qtd. in Sans 30). In his films, Barney specifies this tremulous uncertainty of the characters between personality and state of being by letting one person's movements reflect another's in a separate sequence of events. This can be seen, for instance, when the character Goodyear in Cremaster 1 arranges a handful of grapes and thereby determines the pattern of dance for some girls in a parallel sequence of the film. For Barney, the characters are at once real people, abstractions, and zones of potentiality. They could be termed "per-zones," because they have little depth of character, and instead correlate with a state of flux. Using Deleuze and Guattari's concepts, Barney's per-zones express a human process of deterritorialization, since they do not incarnate a certain human identity or psyche, but rather a territory under constant transformation. One could say that, in general, Barney works to show how something with visual and material form 
can be said to aim at that which has no form. This corresponds with the absence of form paradoxically found by Deleuze and Guattari in the literary forms of Kafka's works.

The figurative connection between Cremaster 2 and Deleuze and Guattari's discussion of becoming-animal is made up of the many concrete alliances between animals and humans in the film. As mentioned above, Cremaster 2 is alive with animals: lots of horses, 12 bison, a bull, and a lapdog among them. Since Gary Gilmore is born as a drone, the bee and swarm play an emphatic role in this order of things. One reason that Barney employs the imagery of bees is that the story of the historical Gary Gilmore took place in Utah, the "Beehive State." Barney thus employs the beehive as form because it functions as a Mormon symbol of societal unity. According to the Mormon faith, the symbol of the beehive suggests that the internal relationship among the faithful is more important for a strong society than any particular individual. ${ }^{8}$ This symbol fits well then within Barney's universe, where characters are taken up as per-zones, rather than fully formed individuals. In Cremaster 2, Barney latches on to this symbol by using 30,000 bees, employing beeswax as his preferred sculptural material, and generally shaping human characters in the image of bees: with wasp waists and in the roles of Queen, drone, and worker bees. These animal-like people make manifest the continuous deterritorialization of the per-zones in the film.

Deleuze and Guattari's description of what becoming-animal means is, obviously, a very positive conceptualization of inhumanity. Here, the inhuman constitutes a creative potential for the human, and becoming-animal is something human beings may strive for. Thus, Deleuze and Guattari share an idea of the inhuman or super-human with thinkers such as Nietzsche and Bataille, according to whom the inhuman constitutes an escape from everything that is all too human and all that attends it in terms of reason and Oedipal psychology and fixed ontologies. ${ }^{9}$ The image of the inhuman as something that is desirable in its radical otherness and non-conformity exemplifies a more general inclination to value the less formed, the affective, and the irrational for their liberatory potential. As a representative of a culture of lawlessness characterized by neglecting toothless, middle-class norms, the convict may paradoxically come to symbolize exactly this freedom and creativity, which in some instances is ascribed to the inhuman. Norman Mailer's idea of the penal system swallowing up brave young men is an obvious example in this regard of the convict figuring as an antidote to the rigid conventionalism of society. This was an idea formulated, among other places, in Mailer's foreword to Jack Henry Abbott's prison memoirs, In the Belly of the Beast (1991[1981]):

Humanimalia: a journal of human/animal interface studies

Volume 6, Number 2 (Spring 2015) 
There is a paradox at the core of penology, and from it derives the thousand ills and afflictions of the prison system. It is that not only the worst of the young are sent to prison, but the best - that is, the proudest, the bravest, the most daring, the most enterprising, and the most undefeated of the poor (xii).

My point here is not that Barney with Cremaster 2 necessarily shares this idea of the convict representing the bravest and invincible segment of a generation. But Barney's preoccupation with Gary Gilmore and his imagined indefiniteness is indicative of the forcefulness and creativity held by the alien, the shapeless, and the inhuman in Cremaster 2 and in Barney's work in general.

This positive perspective on the inhuman as a zone of potentiality and fluctuation, which is mirrored theoretically in Deleuze and Guattari's concept of becoming-animal, is however, only one of several perspectives on the inhuman being negotiated in Cremaster 2. At a more general level, this creative dimension of the inhuman is countered by a completely different kind of inhumanity, which has to do with Gilmore's exposure to a certain lawlessness of the law. As an interpretive model for this other and darker aspect of Gilmore's "animality" as it is presented in Cremaster 2, we can think of Eric Santner's concept of "creaturely life." In On Creaturely Life: Rilke, Benjamin, Sebald (2006), "the creaturely" is Santner's conceptualization of an inhuman dimension of the human, a dimension brought forth when the human is confronted with a particular kind of political power. More specifically, a creaturely life is a life subjected to an exception in the law and therefore caught between law and lawlessness. There is thus a clear conceptual connection between Santner's description of creaturely life and Giorgio Agamben's description of homo sacer and "naked life." This inhuman dimension of the human, which concerns both Santner and Agamben, has to do with human beings' radical powerlessness against the law, when law immodestly allies itself with lawlessness. Santner determines the creaturely in this way: "To bring it to a formula, creaturely life is just life abandoned to the state of exception/emergency, that paradoxical domain in which law has been suspended in the name of preserving law" (22). Just as Deleuze and Guattari begin their discussion of the significance of becominganimal with Kafka, Santner engages with Kafka's oeuvre when identifying the creaturely: "When, at his execution at the end of The Trial, Josef K. exclaims, 'like a dog,' Kafka is thus referring not only to the pathetic scene of K.'s execution but also to the 
larger structure of K.'s experience with the law, one that renders him, precisely, 'creaturely'" (22).

Santner's description of Joseph K.'s "animal death" is a suitable prism through which to understand Barney's Gary Gilmore. In historical terms, Gilmore was executed following a completely different and lawful kind of trial than the one given Joseph K. By representing Gilmore's death as a magnificent prison rodeo, Barney emphasizes the spectacular and theatrical aspects of the death penalty as it is employed in the U.S. In reality, prison rodeos are not a part of the judicial domain and are, of course, never used as instruments of execution. When Barney nevertheless makes use of this cultural ritual to represent the execution of Gilmore, he instigates an encounter between the legal system and the theatre, between law and something apparently very much outside the realm of jurisprudence.

Real life prison rodeos are usually perceived as a festive custom in many American prisons; they are huge events that gathers local communities and give the inmates the opportunity to distinguish themselves as cowboys. The largest prison rodeo occurs biannually in the Angola State Penitentiary in Louisiana, and as the prison rodeo administration writes on its homepage, the rodeo has become big business, from which some of the profits go to the Louisiana tourist industry. ${ }^{10}$ By transforming the execution squad into a prison rodeo, Cremaster 2 thus draws our attention to the entertainment value of the ways in which the death penalty is currently executed. ${ }^{11}$ Whereas Michel Foucault described modern penal history as a movement from the public and spectacular to the private and discrete, Brian Jarvis reminds us in his book Cruel and Unusual (2004) that this history is continuously disturbed by the permanence of the spectacular in American penal culture. Among other things, Jarvis notes that the size of the audience following live broad-casting from the execution of Timothy McVeigh in 2001 by far surpassed the 10,000 who witnessed the last public hanging in the US in 1936 (209). In the wake of Gilmore's execution in 1977, several commentators criticized the media circus that surrounded the event. With the interpretation of the execution as a spectacular and sublime punitive circus, Cremaster 2 suggests that the law continuously enters into alliances with extra-judicial actors, so that contemporary forms of punishment obviously function as entertainment, theatre, and a source of income. Simultaneously, we are reminded of the importance of the capture of animal life - and the ownership of animals - to the historical institution of the rodeo, an institution generating masculinity, wildness, and capital. While in The Trial Joseph $\mathrm{K}$. is executed "like a dog," in Cremaster 2 Gilmore is executed like an outlaw cowboy. He dies on the

Humanimalia: a journal of human/animal interface studies

Volume 6, Number 2 (Spring 2015) 
back of a bull wearing his zebra-suit, and his kinship with the animals is underlined by the ten bison that seem to mourn over him in the arena after his death.

The Two Limits of the Human. Coming back to the distinction I outlined in the introduction, we may roughly divide recent critical thought on "animality" into the two overall categories which I here term "the question of the inhuman" and "the question of the animal." In the previous section I included Deleuze and Guattari's concept of becoming-animal, as well as Santner's concept of creaturely life, in order to illuminate the ambiguity of Gary Gilmore's inhumanity as it is represented in Cremaster 2. These theoretical contributions to contemporary thought on the inhuman describe inhumanity as something related to the bestial, yet in reality unrelated to the natural world of actual animals. Among other contemporary thinkers Judith Butler, Slavoj Žižek, and Giorgio Agamben have also contributed to thinking of the inhuman in a way that employs the animal as a symbol, a metaphor, but which nevertheless discusses "animality" as something ultimately concerning humans and not animals. Žižek, for instance, is in his essay "The Neighbor and Other Monsters" (2005) concerned with the inhuman as a socio-psychological phenomenon. For him, inhumanity signals a "monstrous" excess lodged in human subjectivity, an excess that cannot be tamed or socialized. This form of inhumanity is a dimension of the human that appears when the other loses face or is so thoroughly ashamed that his or her face is no longer recognizable, but rather twisted in a loss of self. For Žižek, as is the case with the other thinkers mentioned here, the inhuman does not denote the difference of the human from the animals but from itself: "the differentia specifica which defines a human being is, therefore, not the difference between human and animal [...], but an inherent difference, the difference between human and the inhuman excess that is inherent to being-human" (175).

Having related Barney's Cremaster 2 to Deleuze and Guattari's ideas on becoming, it seems relevant to note here Nicole Shukin's critique of the concept of becoming-animal and other philosophical formulations of animal alterity. In Animal Capital Shukin holds two main charges against the implications of this concept so central to the work of Deleuze and Guattari. First, and as already mentioned, Shukin disapprovingly notices the abstract character of the figure of animality in this line of thinking. Second, Shukin wonders, as do Hardt and Negri, whether the animal alterity implied, according to Deleuze and Guattari, in becoming-animal can in fact be distinguished from contemporary forms of power and capital. Are not the potentialities and intensities 
involved in becoming-animal exactly the very forms of energy on which capital thrives today, Shukin asks:

In the context of animal capital, there is a great deal at stake in romanticizing affect as a rogue portion of pure energy linked to animality as a state of virtual rather than actual embodiment. [This] is because the field of power can no longer be clearly identified with a restriction on becomings. (31)

I share with Shukin a distrust in "becoming" as a critical concept of counter-hegemonic forces. I also find the call for a materialist critique of the appropriations of animal life today both essential and timely. Nevertheless, I still find merit in "becoming-animal" as an analytical concept that may help us analyze and discuss the meaning not only of contemporary forms of creative and affective alterity, but also of the forms of alliances, collaborations, identifications, and interdependencies, actual or imagined, playing out across, and thus negotiating, the boundaries between human and non-human animals. My sense is that the social imaginary of animals, and the material practices it invites, are far too rich and varied to be fully understood in the opposed terms of animal fetishism or anti-capital.

The second of the two main theoretical categories - "the question of the inhuman" and "the question of the animal" - is distinguished by a more concrete interest in the boundary between human and animal as such, as well as in the political functions this boundary has been made to serve. Jacques Derrida is an important representative of this different "animalistic" thought on the inhuman. The difference between these two overall approaches to the question of inhumanity/animality can be illustrated by two different critiques of Emmanuel Levinas's presentation of the categorical imperative, which according to Levinas emanates from the human face. In "The Neighbor and Other Monsters," Žižek criticizes Levinas for overlooking that categorical imperatives do not stem from the face of the other, but from his or her "facelessness." Žižek finds that a face is far too complete, far too human a symbol to signify the seamy side of the human - that is, the monstrous and inhuman dimension which is what truly requires an ethical response. Conversely, Derrida criticizes Levinas for disregarding the question of whether animal faces call out to our responsibility in the same way as does a human face. In his seminal essay "The Animal That Therefore I Am (More to Follow)" (2002) Derrida's speculates that apparently philosophers such as Descartes, Kant, Heidegger, Lacan, and Levinas have never been observed by attentive animal eyes. "If indeed," Derrida writes:

Humanimalia: a journal of human/animal interface studies

Volume 6, Number 2 (Spring 2015) 
they did happen to be seen furtively by the animal one day, they took no (thematic, theoretical, or philosophical) account of it. They neither wanted nor had the capacity to draw any systematic consequence from the fact that an animal could, facing them, look at them, clothed or naked, and in a word, without a word, address them. (382)

Instead of registering the experience of being observed by an animal, these philosophers have, according to Derrida, made animals into a theorem - into something that is observed, rather than something that observes. Derrida's question therefore becomes whether it really has no implication for the status of animals that we can observe them observing us.

This difference of perspective for Žižek's and Derrida's critiques of Levinas is symptomatic of the difference between the two main categories of theoretical engagement with the question of inhumanity/animality sketched here. In Derrida's discussion, the animal is not primarily a metaphor for a dimension of the human. Rather, Derrida is interested in how we draw the line between human and other forms of life, as well as in the cultural history of this delimitation. Employing the ethological knowledge currently at our disposal, Derrida writes that we simply cannot retain the conception of man being distinguished from non-human life by a straight and clear boundary (415). Beyond the human, we do not find the "animal" as a general, singular category of the living, but rather a multitude of life, which cannot always be neatly described in oppositional binaries such as organic/inorganic or dead/alive. For this reason, the delimitation between human and non-human animals is a differentiated and internally bifurcated boundary. When Derrida is interested in this boundary, it is not to question whether it really exists, or to erase it. The challenge is rather, Derrida suggests, "to multiply its figures, to complicate, thicken, delinearize, fold, and divide the line precisely by making it increase and multiply" (398).

My reason for sketching, somewhat roughly, these two categories of contemporary thought on inhumanity/animality is that Matthew Barney in Cremaster 2 engages with both of them. On the one hand, Gilmore's "animality" exemplifies various aspects of the human traditionally viewed as inhuman. When Barney re-creates Gilmore's story in the shape of a drone, it is not because the historical Gilmore had somehow fallen into the 
sphere of the animal, but because he - as a long term convict and murderer embodied a counter image of what we think of as human, in both negative and positive terms. On the other hand, in Cremaster 2 Barney also questions our conceptions of nonhuman, animal life - that is, the outer boundaries of the human, as it were.

As mentioned, Cremaster 2 is a Noah's Ark in terms of its abundant animal life and it is no less striking how the behavior of these animals does not seem to correspond with our conventional understanding of animal behavior. For instance, the ten bison that take up the arena after Gilmore's death; their movements are elegant and on the beat as in some synchronized sports. While bison typically connote ferocity, speed, and freedom, they here exhibit discipline and organization in their movements, indeed demonstrating very little of what is understood as normal bison behavior. It is a common conception that animals do not mourn their dead, but in Cremaster 2 the solemn and reverent formation held by the bison surely looks like a ritual for the dead. In other words, the film not only posits different concepts about the "animality" of the human. Using an unorthodox manner of creating alliances between animals and humans, Barney also seems to point out that any adjustment of the cultural imaginary of the inhuman is dependent upon simultaneously opening the boundary between human and animal for further reflection.

One of the scenes illustrating how Barney complicates this boundary is a musical scene early in the film. Here we see and hear a drummer, Dave Lombardo from the death metal band Slayer, forcefully beating his instruments, accompanied by 30,000 bees. The musician sits by his drums in a closed studio, while the bees are in a contiguous room "singing" vocal harmony into an old-fashioned microphone. At one point the singer in this two-man metal band starts "buzzing" along into a telephone, while bees crawl in his long dark hair, as if on honey. In the credits we are told that the singer has the voice of Steve Tucker, lead vocalist of Morbid Angel. In this scene Barney visualizes and negotiates the boundary between animal and human in two ways. First, the situation obviously unfolds an interaction across this very boundary. We may, for instance, think of this scene as a nod to Joseph Beuy's famous performance Coyote: I Like America and America Likes Me (1974). Beuys's week-long performance in a New York gallery saw the collaboration between Beuys and a live coyote, where Beuys - using props and strips of felt, pieces of newspaper and a pair of gloves - performed small role-playing segments with the animal. Beuys later noted about the performance that the coyote, called Little John, was for him "an important cooperator in the production of freedom." Little John made it possible for Beuys to approach that which "the human being cannot understand" (qtd. in Wolfe, Zoontologies 150-51). As Beuys did with Coyote, in the

Humanimalia: a journal of human/animal interface studies

Volume 6, Number 2 (Spring 2015) 
musical scene Barney employs an interaction across a highly visible barrier in order to explore that very boundary. The bees seem to be just as originally musical as the human musicians and the piece hence, by involving this egalitarian gesture, appears to be an original collaboration.

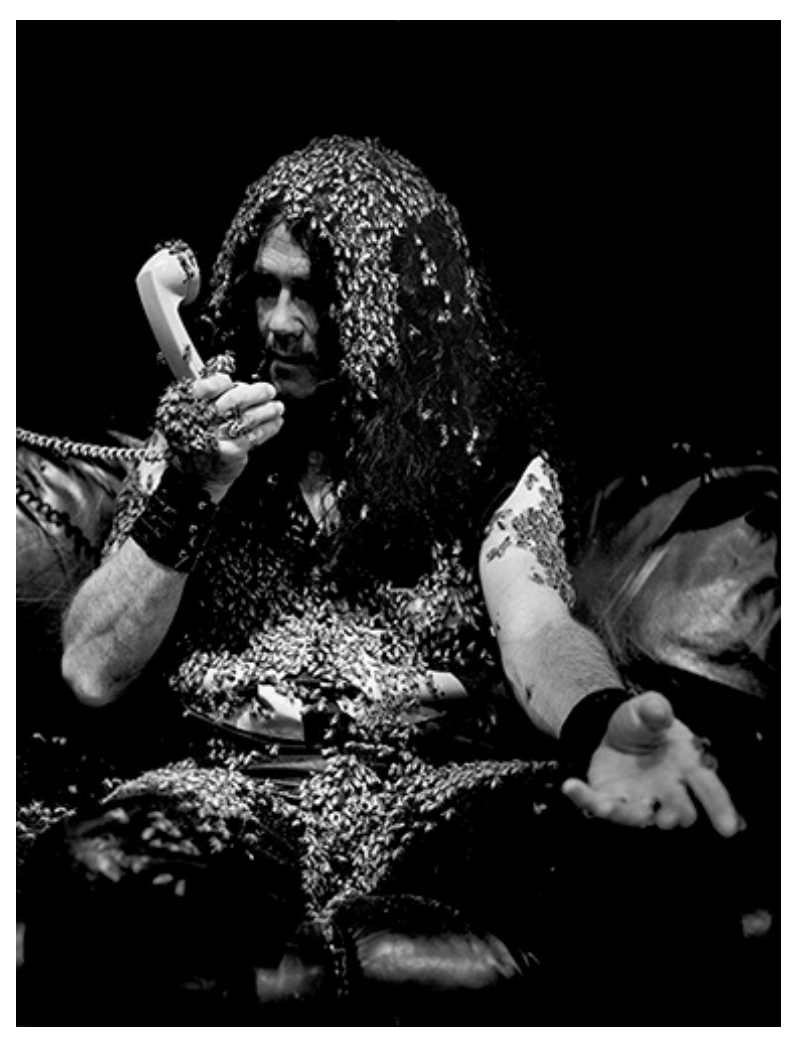

(with permission of the artist)

Second, we may read the scene as a way of problematizing the conventional idea - so central to thinking on the human/animal divide - that we as humans are separated from the animals in and through language. For instance, in "Fonction et champ de la parole et du langage en psychanalyse" from the collection Écrits (1966), Jacques Lacan debates the language of bees. We know about bees, Lacan writes, that they communicate the locations of nectar-rich flowers, through a special figure-of-eight dance. However, the language of bees is a straightforward information system rather than a communication system, because they have fixed reactions for the messages they convey. While people can improvise within their communication systems, animals can only inform, Lacan posits. He simultaneously holds that it is exactly through our insight 
into this inflexibility, this capturedness, of animal "language" that the rich variation in human language becomes clear to us. In regard to the bee-scene in Cremaster 2, the important feature is that this inflexibility, or "imprisonment," of the bees' information system is not clearly enforced. By lifting the bees out of their usual context and allowing them to sing into a microphone, Barney turns bee-language into a sign, the meanings of which are not as fixed as described by Lacan. As the bees stick to the singer's hand, while he growls into the telephone, it seems as if they participate in the conversation.

Frames of Capture. Above, I have shown some of the ways in which Barney in Cremaster 2 engages with questions of inhumanity and animality and thus visually configures some of the questions raised also in the contemporary critical thinking on these issues. Perhaps the most precise contribution by Cremaster 2 to the more theoretical work on these issues, however, is the film's suggestion to connect the ways in which we draw anthropological and zoological lines to the ways in which we think with confinement and captivity as frames. Various forms and degrees of confinement, both symbolic and material, make up the thread in the film, from Gilmore the convict, through animals strikingly un-captured by their natural environment, to the figure of Harry Houdini. By connecting these two domains - the production of inhumanity and animality, on the one hand, and figures of confinement, on the other - the film draws our attention to an obvious, yet so far mostly unexplored, common material platform for the production and distribution of inhumanity and animality, namely confinement and captivity. When confinement is evoked as a practice implying re-production of a certain idea of the human it is mainly via what is frequently called "the holocaust analogy," the comparison of today's animal factory farms to the camps of the Third Reich. Cremaster 2 invites us, I would suggest, to develop in new directions a thinking on captivity and confinement as symbolic and material practices vital to the production of the human over and against both the "less than human" and non-human animals.

In both popular culture and critical theory the concentration camps of the Second World War figure as limit cases in the histories of both the often banal brutishness of humans and the dehumanization of the human. Correspondingly, the camp as a specific organization of human life typically constitutes the historical raw material for reflection on the inhuman propensities of human beings. This applies explicitly to the various examinations - Santner's and Agamben's among them - of "naked" and "creaturely" human life without legal or political rights. But it applies also to Judith Butler's significant analysis of the de-subjectifying functions of Guantanomo Base. As a spatial manifestation of a particular kind of lawless sovereignty, which strips the individual of

Humanimalia: a journal of human/animal interface studies

Volume 6, Number 2 (Spring 2015) 
human rights, the camp seems to us the location par excellence for dehumanizing human beings.

But camps and cages are, of course, also sites for the management of non-human animals. In the essay "The Animal That Therefore I Am (More to Follow)," Derrida thus suggests that the extreme limit case of the camps of the Second World War resonates in our current conception and treatment of animals. As Derrida sees it, the denial in the history of philosophy of animals observing and truly watching humans is a symptom of a larger, collective disavowal, which over the last centuries has made it possible for humans violently to transform animals and their natural environment. The kind of violence Derrida has in mind is, for instance, genetic experimentation, artificial insemination, and cloning of animals for the benefit of the human animal:

As if, for example, instead of throwing people into ovens or gas chambers (let's say Nazi) doctors and geneticists had decided to organize the overproduction and overgeneration of Jews, gypsies, and homosexuals by means of artificial insemination, so that, being more numerous and better fed, they could be destined in always increasing numbers for the same hell, that of the imposition of genetic experimentation or extermination by gas or by fire. In the same abattoirs. (395)

Comparing such "abbatoirs" - factory farms and slaughterhouses - to the extermination camps of the Third Reich Derrida asks us to consider if not our very humanity is today at stake in the "animal extermination camps" we have somehow come to accept as part of late modern life? What would be the consequences for our shared ideas about the boundary between animals and humans, if we were, finally, to recognize that also animals suffer and therefore should be ensured some kind of rights? ${ }^{12}$

On the one hand, then, we may think of the camp and the camp-like prison as concrete, institutional places of transition between the human and that which is less than human - and, in an argument like Derrida's, as a place of transition between an animal life worth living and that life which is less than animal, so to speak. On the other hand, we should also note that there is a strong tradition in both philosophy and popular culture to imagine the various limits among the human, the inhuman, and the non-human by

Devika Sharma - "The Captive Imagination: Inhumanity, Animality, and Matthew Barney's Cremaster 2" 
frames of confinement and captivity. In the history of philosophy, this tradition receives its clearest expression in Martin Heidegger's polemic against Rainer Marie Rilke's description of animals as being more genuinely free than human beings. For Rilke, animals were free because they have access to the open spaces of the world, while humans are forever captured in a claustrophobically enclosed world, condemned to a sort of slavery due to their perpetual self-reflexivity. However, according to Heidegger, Rilke made the same mistake as did Nietzsche, namely to conceive of the animals' ostensibly instinctual will as primary and human thought and consciousness as pale derivations thereof, whereby the animal was elevated into something like a superhuman state. For Heidegger, the ability to experience freedom in Being, das Frei des Seins, is on the contrary what constitutes the human and delimits it from animals (226). While the animal, according to Heidegger, will always remain imprisoned, captured by its environment, human life unfolds in an open space of opportunity. ${ }^{13}$

Both Agamben and Santner have employed Heidegger's critique of Rilke's "glorification of the animal" to shape their own concepts of naked and creaturely life, respectively. They have, so to speak, internalized the Heidegger-Rilke discussion about the differences in human and animal freedom, so that this difference is now described instead as a difference traversing the human itself. In The Open: Man and Animal (2004), Agamben describes the "anthropological machines" whereby the human has historically isolated and encapsulated the very aspects of its humanity, which for some reason or other were perceived as non-human, thereby re-producing the human as fully human. According to Agamben, the human has shaped itself as human by expelling animal life while simultaneously containing it: "[T] he world [that] had been opened for man only by means of the suspension and capture of animal life," (80; emphasis added). As a product of the various anthropological machines of history, the human conceives itself as a dyad of something that is human and thereby free and something that is nonhuman and thereby captured and hidden. ${ }^{14}$ When Kafka's Joseph K. becomes Santner's preferred image of the creaturely, inhuman life, it is exactly because K.'s position in regard to the law can be likened to the animal's encaged relation to its environment as described by Heidegger. For Santner, the creaturely is a dimension of the human, which is generated by a biopolitical power, and which makes man seem just like the animal in its captured relation to the world.

My aim in this short exposition has been to strengthen the idea merely intimated by Cremaster 2 that our conceptualization of the various limits between the human and its others is deeply related to the ways in which we conceive of freedom and bondage. As I mentioned in the introduction, we often use prisons, captivity, and simple lack of

Humanimalia: a journal of human/animal interface studies

Volume 6, Number 2 (Spring 2015) 
freedom as discursive and visual frames for perceiving the less than human. One example could be automatism, which appears to be immanent to the framing of the criminal as an animal-like person. From Descartes we have the idea of the animal body as a nature-bound and functional machine - an automaton. When one conceives of the criminal as a killing-machine, the criminal partakes in this cultural conception of the animal's mechanistic, nature-bound character - its fixed and somehow captured relation to its environment. But of course it is not only philosophers who employ metaphors of imprisonment as tools for thinking and explicating the line distinguishing the human from the inhuman and the non-human. In Oliver Stone's classic movie Natural Born Killers (1994) the serial killer Mickey at one point connects his own criminality with the automatic behavioral pattern of an animal: "The wolf doesn't know why he's a wolf," he explains in court. According to the common image of the criminal as an animal, the perpetrator borrows from the animal's ostensible lack of freedom, so to speak, its mechanical "captivity' in its surroundings.

Heidegger used the term "Benommenheit" [takenness] in order to describe the animal's captivity in and by its world. That the animal is imprisoned by its environment paradoxically also came to mean for Heidegger that the animal, to some degree, is intensely open to this very environment. This basic ambivalence and complexity of thinking "animality" through the framework of confinement is repeated in contemporary cultural theory and played out as well in the visual engagement with captivity in Cremaster 2. Agamben, for instance, describes the process whereby the human constitutes itself as human rather than inhuman in the following unequivocal way: "Man suspends his animality and, in this way, opens a 'free and empty' zone in which life is captured and a-bandoned \{ab-bandonata\} in a zone of exception" (79; emphasis added). This complex topography, which is presented by Agamben to describe the relation between the human and the inhuman, complicates the common idea that the humanity of the human lies in a certain freedom with which human beings relate to their surroundings.

In Cremaster 2, Barney is obviously interested in this ambivalent notion of animals as particularly free in comparison with man, or - in reverse - as particularly "imprisoned" and "enslaved" as compared to man. As we have seen, for Barney bison are not particularly undisciplined compared to humans, while the language of bees, conversely, does not seem more fixed than human language. Cremaster 2 thus visualizes

\section{Devika Sharma - "The Captive Imagination: Inhumanity, Animality, and Matthew Barney's Cremaster 2"}


the fundamental ambivalence, whereby the animal is typically conceived as at once free and confined. This fundamental ambivalence in the understanding and representation of animal life is important also because our conceptions of the "animality" of man seem to be modeled on how we conceive the lives of actual animals. This is why - Barney's suggestion seems to be - we cannot hope to alter the imaginary of the inhuman without simultaneously complicating the limit between animals and humans. To which extent are the forms of freedom we cherish dependent upon the discursive and institutional confinement of "less than human" and animal life? What are the spaces in which the negotiations of human/animal and free/confined play out today? What Cremaster 2 suggests, then, is that a further understanding of how we produce humanity, inhumanity, and animality, respectively, must include a reflection upon practices and ideas of confinement and captivity.

On the symbolic level, such reflection is, I would suggest, exactly what Barney uses the figure of Harry Houdini for in Cremaster 2. As is well known, the historical Harry Houdini (1874-1926) significantly altered his contemporaries' ideas of captivity. More specifically, he both invoked and subverted the idea of the prison as a hermetically sealed location. Having been a locksmith apprentice in New York for a short while, Houdini took up a number of handcuff tricks, which became a huge success when he was traveling in Europe. Here Houdini challenged the police to chain him and put him in prison, from where he would usually break out. Back in the U.S. he expanded his repertoire, such that prison cells, handcuffs, and strait jackets were now supplemented with escaping locked containers filled with water. In Houdini's Box: The Art of Escape (2001), the British psychoanalyst Adam Philips suggests that Houdini's continuously firm grip on the collective imagination is based on the idea that human life can, in general, be understood as serial attempts at escaping one or the other restraint, be they material or immaterial. For Barney, however, Houdini is not only an emblematic condensation of a certain theme, but also an important figure in terms of poetics.

Harry Houdini's escape from his beeswax cabinet sets the stage for the final scenes of Cremaster 2. Here, we are located among ghostly animal lives in the shape of stuffed animals in a large building reminiscent of a railway station foyer, a reference to the 1893 Chicago World's Fair, where the real Harry Houdini performed one of his famous metamorphoses. Into this almost empty space enters the magician Baby Fay La Foe, and a rather short exchange unfolds between the two, the escape artist and the magician, who is dressed as a queen bee. La Foe mischievously suggests that Houdini's metamorphoses are not at all real, but merely a kind of bodily demonstration. Over and

Humanimalia: a journal of human/animal interface studies

Volume 6, Number 2 (Spring 2015) 
against this, Houdini aggressively insists that his art truly is one of transformation. Speaking in the third-person, Houdini says:

I can assure you that each time I challenge myself to escape from a locked trunk, a real transformation does take place. Within metamorphosis, Houdini becomes part of the cage that contains him. He enters the lock that seals his bonds. He begets the lock. It becomes a part of him. The walls that imprison his body come open (Barney 1999, transcription of final scene).

As noted above, it is a common observation that the freedom of the human is what makes it human. In Cremaster 2, Barney has, however, employed the figures of the convict, the escape artist, and some memorably "non-animal" animals to complicate the ways in which we employ captivity as framework when imagining the in- and nonhuman. If we were to understand, as I will suggest, Houdini's last words in Cremaster 2 as a poetological mission statement for Barney, we might say that Cremaster 2 is an experiment in altering the common conceptions about the human's humanity in much the same way as Houdini treats his captivity. For Barney, Houdini and his escape artistry are then not merely a way of showing that human life always entails both limitations and attempts at escaping those limitations. Houdini's role in Cremaster 2 is also to make visible how we continuously produce the human, the inhuman, and the animal, in an on-going negotiation of confinement and freedom.

\section{Notes}

1. In 1994 journalist Adam Nossiter reported in The New York Times from a session held by the Mississippi Legislature that revolved around enacting new restraints on the state's prisoners, including the striped uniforms with the word "convict" inscribed on the back. Nossiter quotes Representative Mack McInnis, a Democrat, in The New York Times saying: "'When you see one of these boogers aloose, you'll say, 'I didn't know we had zebras in Mississippi'" (Nossiter).

2. Judith Butler's analysis of the "bestialization" of the prisoners in Guantánamo as they were represented in photos published by the Department of Defense illustrates the ways in which this metaphor materializes not least in U.S. war prisons. Butler writes, "There is a reduction of these human beings to animal status, where the animal is figured as out of control, in need of total restraint" (78). We need not, however, limit

\footnotetext{
Devika Sharma - “The Captive Imagination: Inhumanity, Animality, and Matthew Barney's Cremaster 2"
} 
this precise analysis to war prisons abroad. Within the US, the so-called supermaximum security facilities continue to proliferate and they constitute yet another example of the ways in which the current American administration of punishment can be said to resemble some sort of pest control. What is significant in this regard is the figuring of the supermax prisoner as a risk-bearing creature who should by all means be maximally segregated from the rest of the population. In supermax prisons inmates are typically confined in their cells for 22 to 23 hours a day with most verbal communication occurring through intercom. As Pizarro and Stenius write: "These institutions limit human contact to instances when medical staff members, clergy members, or counselors stop in front of inmates' cells during routine rounds. Physical contact is limited to being touched through security doors by correctional officers while being put in restraints or having restraints removed" (251).

3. This way of distinguishing two lines of critical thinking about the boundaries of the human should not, of course, be overstated. Surely, the production of inhumanity is a most pressing issue also for Derrida, Wolfe, Shukin, and Peter Singer. Rather than as essential difference, then, I consider the distinction one of emphasis. For introductions to animal studies see Cavell; Wolfe, Animal Rites and Zoontologies; Kalof and Fitzgerald; and Atterton and Calarco.

4. Surely, this sense of hermeticism also stems from the fact that the films are only seldom shown to the public and are exceedingly expensive to acquire. My concern here is with the thematic issue of inhumanity examined by Cremaster 2 and I am thus not focusing my attention on the Cycle as a particular aesthetic universe or on the institutional and financial structures of its production and reception. See Keller and Ward for a critical examination of the paradoxical mix of avant-garde and blockbuster strategies of the Cycle. See also the official homepage for an impression of the universe of the Cycle: www.cremaster.net.

5. Art historian and curator Nancy Spector gives the most thorough exposition of the expressions, effects, and recurrent themes in Barney's work; indeed, her analyses of the individual performances, installations, and films are indispensable for working with this strange universe. See Spector for an interpretation of the overall issues in the Cremaster Cycle.

6. In fact, we know this only from the credits, from which we learn that Gary Gilmore is played by Matthew Barney and that the other characters are Baby Fay La Foe, Frank Gilmore, Bessie Gilmore, Nicole Baker, Harry Houdini, and Johnny Cash. Symbolism is

Humanimalia: a journal of human/animal interface studies

Volume 6, Number 2 (Spring 2015) 
highly complex in the Cremaster universe and since there is no dialogue or plot as such to support our inferences we must know the story of Gary Gilmore if we are to identify the individual scenes as references to his life.

7. According to Mailer, a typical observation made by the people around Gilmore was that he had a wild look in his eyes, and this perceived wildness is reflected for instance in Mailer's description of Gilmore as "a wildcat in a bag" and in the way his goatee ostensibly suggested an underlying ferocity (Executioner's Song 274).

8. See Cannon for a discussion of the Mormon understanding of this symbol.

9. In this context of captivity, Bataille's oft-cited 1936 programmatic text in Acéphale may serve as an illustrative example. Commenting on the cover art of a decapitated, naked man, Bataille wrote: "Man escaped from his head like the condemned man from his prison. He found beyond him not God, who is the prohibition of crime, but a being who doesn't know prohibition" (181). For Bataille, the free, headless man is more than a man; he is superhuman, since he has liberated himself from the slavery of human life.

10.See http://www.angolarodeo.com. See also the excellent documentary by Jonathan Stack and Elizabeth Garbus: The Farm: Life Inside Angola Prison.

11 See Michelle Brown's The Culture of Punishment, especially chapter 4, for a precise critique of prison tourism as well as of the "penal spectatorship" to which the prison tourism in the U.S. contributes.

12. Of the several discussions within animal studies of this "holocaust analogy," I think J.M. Coetzee's literary examination in The Lives of Animals of such analogies is still among the most vivid. See also the pointed commentaries by Peter Singer, Marjorie Garber, and others, in this rich volume.

13. Heidegger used the concept of "Benommenheit" to describe the essence of animals. This means being engrossed or captivated. This animal captivation paradoxically suggests an openness that is more intense than the human experience of the world, because it is so thoroughly swallowed up by its environment. The animal is therefore open to its surroundings, its environment, but in a closed and enslaved way, Heidegger

\footnotetext{
Devika Sharma - "The Captive Imagination: Inhumanity, Animality, and Matthew Barney's Cremaster 2"
} 
argues in the lectures collected in Die Grundbegriffe der Metaphysik. Welt - Endlichkeit Einsamkeit (see especially chapter 4).

14. In the context of this essay, two critiques of Agamben's argument seem particularly relevant to note here. To Steven Connor, Agamben's description of the "anthropological machines" that produce the human by separating the human from animal amounts to yet another way of formulating the exceptionality of the human. Connor writes: "Man is now not the only creature that is able to grasp its own essence, but the only creature that is able to experience the anguish of its lack of essence." A more comprehensive critique is to be found in Cary Wolfe's Before the Law. Here, Wolfe holds that Agamben's unwilled contempt for bare life and the animality that this life entails leaves no room for a political thinking on animal life as the unprotected life par excellence (24-27).

\section{Works Cited}

Abbott, Jack Henry. In the Belly of the Beast: Letters from Prison. 1981. New York: Vintage, 1991.

Agamben, Giorgio. The Open: Man and Animal. Stanford: Stanford UP, 2004.

Atterton, Peter, and Matthew Calarco, eds. Animal Philosophy: Essential Readings in Continental Thought. London and New York: Continuum, 2004.

Bataille, Georges. "The Sacred Conspiracy." Visions of Excess: Selected Writings 1927-1939. Trans. Allan Stoekl. Minneapolis: U Minnesota P, 1985.

Brown, Michelle. The Culture of Punishment: Prison, Society, and Spectacle. New York: New York UP, 2009.

Bunker, Edward. The Animal Factory. [1977]. New York: St. Martin's Minotaur, 2000.

Butler, Judith. Precarious Life: The Powers of Mourning and Violence. New York: Verso, 2004.

Cannon, Hal, ed. The Grand Beehive. Salt Lake City: U of Utah Press, 1980.

Cavell, Stanley, ed. Philosophy and Animal Life. New York: Columbia U P, 2008.

Humanimalia: a journal of human/animal interface studies

Volume 6, Number 2 (Spring 2015) 
Coetzee, J.M. The Lives of Animals. Princeton UP, 2001.

Connor, Steven. "Thinking Perhaps Begins There: The Question of the Animal." Textual Practice 21 (2007): 577-84.

Cremaster 2. Matthew Barney (dir.) New York: Barbara Gladstone, 1999. Film.

Deleuze, Gilles, and Felix Guattari. Kafka: Toward a Minor Literature. Trans. Dana Polan. Minneapolis: U Minnesota P, 1986.

—, and Felix Guattari. A Thousand Plateaus: Capitalism and Schizophrenia. Minneapolis: U Minnesota P, 1987.

Derrida, Jacques. "The Animal That Therefore I Am (More to Follow)." Trans. David Wills. Critical Inquiry 28:2 (2002). 369-418.

The Farm: Life Inside Angola Prison. Jonathan Stack and Elizabeth Garbus, dirs. Gabriel Films, 1988. Film.

Heidegger, Martin. Die Grundbegriffe der Metaphysik. Welt - Endlichkeit - Einsamkeit. Gesamtausgabevol. v. 29/30. Manfred S. Frings, ed. Frankfurt am Main: Vittorio Klostermann, 1983.

Jarvis, Brian. Cruel and Unusual: Punishment and US Culture. London: Pluto Press, 2004.

Kalof, Linda, and Amy Fitzgerald, eds. The Animals Reader: The Essential Classic and Contemporary Writings. Oxford: Berg, 2007.

Lacan, Jacques. "Fonction et champ de la parole et du langage en psychanalyse." Écrits. Paris: Seuil, 1966.

Mailer, Norman. "Introduction." Jack Henry Abbott, In the Belly of the Beast: Letters from Prison. 1981. New York: Vintage, 1991. 
—. The Executioner's Song. 1979. New York: Vintage, 1998.

Natural Born Killers. Oliver Stone, dir. Warner Bros., 1994. Film.

Nossiter, Adam. "Making Hard Time Harder, States Cut Jail TV and Sports." New York Times 17 September 1994.

Phillips, Adam. Houdini's Box: The Art of Escape. New York: Faber \& Faber, 2001.

Pizarro, Jesenia, and Vanja M. K. Stenius. "Supermax Prisons: Their Rise, Current Practices, and Effect on Inmates." The Prison Journal 84.2 (2004): 248-64.

Sans, Jérôme. "Matthew Barney: Héros modernes/Modern Heroes." Art Press 204 (1995): 25-32.

Santner, Eric L. On Creaturely Life: Rilke, Benjamin, Sebald. Chicago: U of Chicago P, 2006.

Shukin, Nicole. Animal Capital -- Rendering Life in Biopolitical Times. Minneapolis: U of Minnesota P, 2009.

Spector, Nancy. "Only the Perverse Fantasy Can Still Save Us." Matthew Barney: The Cremaster Cycle. Nancy Spector, ed. New York: Guggenheim Museum Publications, 2002. 2-90.

Wolfe, Cary. Animal Rites: American Culture, the Discourse of Species, and Posthumanist Theory. Chicago: U of Chicago P, 2003.

- Before the Law: Humans and Other Animals in a Biopolitical Frame. Chicago: U Chicago P, 2012.

_ ed. Zoontologies: The Question of the Animal. Minneapolis: U of Minnesota P, 2003.

Žižek, Slavoj. "The Neighbor and Other Monsters." The Neighbor: Three Inquiries in Political Theology. Slavoj Žižek, Eric L. Santner and Kenneth Reinhard, eds. Chicago: U of Chicago P, 2005.

Humanimalia: a journal of human/animal interface studies

Volume 6, Number 2 (Spring 2015) 